\title{
THE PROFILE OF SELECTED SAMPLES OF CROATIAN ATHLETES BASED ON THE ITEMS OF SPORT JEALOUSY SCALE (SJS)
}

\author{
Joško Sindik, Institute for Anthropological Research, Zagreb, Croatia \\ Ana-Mary Bauer Čuk, Institute for Anthropological Research, Zagreb, Croatia
}

\begin{abstract}
The role of jealousy in sport, as a negative emotional reaction, accompanied by thoughts of inadequacy when compared to others, is the issue of this article. This study had a purpose to define the characteristic profiles of the Croatian athletes, based on single items of Sport Jealousy Scale (SJS II), labeled by several variables: gender, type of sport, age group. Purposive sample of 73 athletes competing at Croatian championships in different sports (football, bowling, volleyball and handball) were examined with Croatian version of SJS-II. Three clusters obtained are similarly balanced, according to the number of cases in each cluster. The most simply explained, clusters clearly differentiate the most jealous, moderately jealous and slightly/low jealous athletes. Among the features of the athletes in each cluster, in the most jealous (first) cluster are the athletes from team sports, women and older athletes. Females, bowling athletes, athletes from individual (coactive) sports and the youngest athletes are the least jealous (grouped in third cluster).
\end{abstract}

Keywords: Cluster analysis, Croatian athletes, Sport jealousy

\section{PROFIL IZABRANIH UZORAKA HRVATSKIH SPORTAŠA BAZIRANIH NA ČESTICAMA SKALE SPORTSKE LJUBOMORE (SJS)}

Sažetak

Problematika ovog članka odnosi se na ulogu ljubomore u sportu, koja se tumači kao negativna emocionalna reakcija praćena mislima o vlastitoj neadekvatnosti u slučaju usporedbe pojedinca s drugima. Cilj ovog istraživanja jest definirati karakteristične profile hrvatskih sportaša, bazirane na pojedinačnim česticama Skale sportske ljubomore (SJS II) na osnovi nekolicine varijabli: spol, dobna skupina i vrsta sporta. Tri dobivena klastera su podjednako uravnoteženi prema broju slučajeva u svakom od klastera.Najjednostavnije objašnjeno, klasteri jasno razlikuju najviše ljubomorne, umjereno ljubomorne i nisko ljubomorne sportaše. Među značajkama sportaša u svakoj od skupina, u najljubomornijem (prvom) klasteru su sportaši iz timskih sportova, žene i stariji sportaši. Žene, kuglači, sportaši iz pojedinačnog (koaktivnog) sporta i najmlađi sportaši su najmanje ljubomorni (grupirani su u trećem klasteru). 
Ključne riječi: klaster analiza, hrvatski sportaši, sportska ljubomora

TIMS Acta (2016) 10, 85-91

\section{Introduction}

The issue of this article is an attempt to determine the profile of Croatian athletes based on their level of sport jealousy, with a purpose to establish the directions for improving coaches' work. The initial presumption of the authors was that some variables, such as gender and type of sport, could provide useful guidelines in this attempt.

There are a number of antecedents of social comparison jealousy: Salovey \& Rodin (1984) argue that social comparison jealousy occurs when one receives negative information about oneself from another and when the other person is similar to oneself. Silver \& Sabini (1978) think that social comparison jealousy results when one person diminishes the status or selfesteem of another person. Bers \& Rodin (1984) found that people react in a jealous manner when another person is superior in some way or when another achieves something that is desired. In addition, the level of importance of the event can greatly affect the intensity of social comparison jealousy. Social comparison jealousy in sport, therefore, may be very common because athletes are similar and constantly compare themselves to each other (Kamphoff, Gill, \& Huddleston, 2005).

The research of jealousy had been conducted mostly outside the sport setting, especially in the area of romantic relationships (Bers \& Rodin, 1984; Mathes \& Severa, 1981) where jealousy is defined as having a belief or suspicion that a relationship is in danger of being lost (Kamphoff, Gill, \& Huddleston, 2005). Some authors (Bers \& Rodin, 1984; Silver \& Sabini, 1978) went further, indicating envy and jealousy share strong similarities because both constructs produce similar emotions, cognitions and behaviors. Other authors (such as Bringle, Roach, Andle, \& Evenbeck, 1977; 1979) describe jealousy as a wish to be in a person's shoes (or actually wanting to be another person), contrary to envy as wanting to own their shoes, wanting "another's possessions, attributes or reputations". Jealousy represents a triadic relationship (involving three people), whereas envy is a dyadic relationship that involves two people (Bers \& Rodin, 1984).

Bers \& Rodin (1984) name a separate category of jealousy in romantic relationships labeled "social relations jealousy" which is defined as challenging one's exclusivity in a relationship and can be 'interpolated' in various sport situations. Hence, knowing that social comparison jealousy is likely to the sport setting in situations when one athlete diminishes another athlete's status, is superior in some way, is similar to the athlete and if the event is important (Bers \& Rodin, 1984; Salovey \& Rodin, 1984; Silver \& Sabini, 1978), social comparison processes in sport are studied according to the role of jealousy in sport. In this context, jealousy is understood as a negative emotional reaction that is accompanied by thoughts of inadequacy when compared to others.

Pease (1987) developed the Social Comparison Jealousy Scale (SCJ) and investigated the impact of social comparison jealousy to sport team's cohesion at 71 team sport participants. Results indicated a small negative, but non-significant correlation between jealousy and team cohesion. Pease found a one-factor structure, which he attributed to difficulties when differentiating envy and jealousy (Kamphoff, Gill, \& Huddleston, 2005). SchellingKamphoff \& Huddleston (1999) compared intensity of jealousy experienced by male and female athletes. They used the Revised Self-Report Jealousy Scale (SRJSII; Bringle et al., 1977) as a model to develop the Sport Jealousy Scale (SJS), which was then administered to 233 track and field athletes. The results revealed males and females were moderately jealous, averaging 2 on a scale of 5 .

Parker (2001) used the Revised Sport Jealousy Scale (SJS-II) to examine levels of jealousy and self-esteem among athletes involved in both individual and team sports. She found that $77.3 \%$ of all athletes reported that they had experienced at least one of eleven situations described in the Revised SJS. Females (88\%) were more likely than males (66\%) to have experienced one of the situations mentioned. In the same research, freshmen and sophomore starters indicated more jealousy than 
freshmen and sophomore nonstarters.

Jealousy may also have a negative impact on team cohesion, which is of great importance in team sports (comparing with individual sports where success is more exclusively based on an individual's performance). Hence, it is important to understand cohesion of both interacting and co-acting teams and possible negative influence that jealousy may inflict on cohesion.

This study is an extension of the study conducted by Sindik \& Lorger (2011), who revealed that Croatian athletes indicated that they experienced social comparison jealousy, while the measuring instrument Revised Sport Jealousy Scale (SJS-II) demonstrated good psychometrical properties (reliability type internal consistency and construct validity), but the original version of SJS-II is shortened to 9 items. Authors obtained the statistically significant differences in the jealousy between the Croatian athletes in several independent variables, with higher jealousy scores among athletes engaged in team sports, women, lower competition ranks and juniors.

This study has a purpose to define the characteristic profiles of the Croatian athletes, based on single items of SJS II, labeled by several variables: gender, type of sport, age group. The hypothesis was that the two or more distinctive characteristic profiles of the Croatian athletes based on the aspects of their sport jealousy will be found.

\section{Method}

\section{Participants}

Purposive sample of 73 athletes competing at Croatian championships in different sports were examined, consisted of teams who are competing in First Women Football League, Second Women Volleyball League, First Women Handball League, Third Men Football League, First Bowling League (Men and Women - selected candidates for the national teams). All athletes in chosen teams that were available were tested. Overall number of the athletes according to relevant labeling variables can be observed in Table 1 . All volleyball and handball athletes were female. Eight football players were female and 17 were male. Eight bowling athletes were male, and 11 were female. The mean age of the athletes was 21.8 years, with a range of 15 to 54 years old.

\section{Measures}

The questionnaire used in the study is Croatian shortened version of the Revised Sport Jealousy Scale (SRJS-II). The SRJS-II is used to measure the amount of social comparison jealousy an athlete experiences in sport. The SRJS-II applied on this sample of participants contained all 11 items with Likert-type estimation scale, ranged from 1 (pleased) to 5 (extremely upset). The reliability of the original scale was high $(\alpha=.87)$, and the concurrent validity with the non-romantic items on the SRJS-II was reported as moderate ( $r=.43$ ) (Kamphoff, Gill, \& Huddleston, 2005). Croatian version of the SRJS-II was translated and adapted by Sindik \& Lorger (2011).

Factor analysis of the 9-item Croatian version of the SRJS-II revealed one-factor structure, with $37 \%$ of the variance explained. Nine-item revision of the Sport Jealousy Scale in the study conducted by Sindik \& Lorger (2011) demonstrated good reliability type internal consistency (Cronbach's $\alpha=0.78)$.

\section{Procedure}

In order to collect the data required, coaches from selected teams from different sports were contacted by phone, to obtain their permission of administering the questionnaires to their athletes. Five coaches agreed to participate with their teams. After obtaining permission from the coaches, researchers had met the athletes before or during their training session. The administrator emphasized that participation was voluntary. Athletes had also been encouraged to decline participation if felt that this activity shall affect their performance regarding their upcoming sport competition. The researcher briefly explained to the participants that the questionnaire is used to assess the relations and emotions within their team. Complete confidentiality was guaranteed, no names were requested. It is emphasized that the coach of the athletes in certain team would not have access to the data, and only group statistics would be reported and disseminated to him/her. 
After completing the questionnaire, the athletes returned it to the researcher, along with the signed informed consent.

\section{Statistical Analysis}

Statistical analysis was performed by statistical package SPSS for Windows 20.0. The K-means nonhierarchical cluster analysis was used, which was applied on the ordinal variables (items of SJS-II scale). The initial cluster centers were automatically determined and a three-cluster solution was found as the most suitable, since a larger number of clusters results in clusters containing a smaller number of entities, unevenly distributed. After performing cluster analysis, individuals (cases) were distributed according to the variables gender, type of sport and age group. Frequency of distribution of participants in certain clusters with respect to these variables was analyzed, while the differences in distributions of the cases across clusters are tested by Chi-square test (at the level of significance $\mathrm{p}<0.05)$.

\section{Results}

K-means clustering based of the items of SRJS-II on the sample of Croatian athletes are presented in Table 1. Three clusters obtained are almost equally balanced, according to the number of cases in each cluster.

Table 1. K-means clustering based of the items of Sport jealousy scale 2 on the sample of Croatian athletes (labeled by several variables)

\begin{tabular}{|c|c|c|c|c|}
\hline & & Cluster & & \\
\hline & 1 & 2 & 3 & \\
\hline $\begin{array}{l}\text { A teammate is more popular than you are } \\
\text { with the other members of the team. }\end{array}$ & 1.50 & 2.77 & 1.19 & \\
\hline $\begin{array}{l}\text { A teammate receives more scholarship mon- } \\
\text { ey even though you both have equal ability. }\end{array}$ & 1.67 & 2.91 & 1.85 & \\
\hline $\begin{array}{l}\text { No matter what you do, your coach seems to } \\
\text { be more interested in a teammate's perfor- } \\
\text { mance than in your performance }\end{array}$ & 3.13 & 2.86 & 2.04 & \\
\hline $\begin{array}{l}\text { In practice, your coach encourages another } \\
\text { athlete more than you. }\end{array}$ & 3.42 & 2.95 & 2.15 & \\
\hline $\begin{array}{l}\text { You and your teammates have worked hard } \\
\text { all season. When the team wins a big com- } \\
\text { petition, you are not recognized for your } \\
\text { contribution to the win }\end{array}$ & 2.71 & 3.23 & 1.78 & \\
\hline $\begin{array}{l}\text { A teammate seems to be receiving preferen- } \\
\text { tial treatment by the coaching staff. }\end{array}$ & 3.71 & 2.64 & 1.67 & \\
\hline $\begin{array}{l}\text { The local paper interviews many of your } \\
\text { teammates and fails to interview you. }\end{array}$ & 3.00 & 2.73 & 1.41 & \\
\hline $\begin{array}{l}\text { A teammate rarely works hard in practice, } \\
\text { however,during competition he/she per- } \\
\text { forms better than you }\end{array}$ & 3.50 & 2.95 & 2.04 & \\
\hline $\begin{array}{l}\text { Your coach seems to have a better relation- } \\
\text { ship with your teammate than with you. }\end{array}$ & 4.04 & 2.05 & 1.85 & \\
\hline $\begin{array}{l}\text { Teammates' names are mentioned on the } \\
\text { radio from your last contest. Your name is } \\
\text { not mentioned. }\end{array}$ & 3.04 & 3.09 & 1.56 & \\
\hline $\begin{array}{l}\text { Some teammates never seem to worry } \\
\text { about their weight. On the other hand, you } \\
\text { have to monitor what you eat. }\end{array}$ & 2.88 & 2.36 & 1.70 & \\
\hline Number of Cases in each Cluster (N) & 24 & 22 & 27 & $\begin{array}{l}\text { Chi-Square } \\
\text { Tests }\end{array}$ \\
\hline males (25) & 3 & 14 & 8 & $13.74 * *$ \\
\hline females (48) & 21 & 8 & 19 & $(d f=2)$ \\
\hline
\end{tabular}


Sindik, J., Bauer Čuk, A. M. - Hrvatski sportaši i skala sportske ljubomore 2016. Fakultet za sport i turizam, Novi Sad, TIMS Acta 10, 85-91

\begin{tabular}{lcccr}
\hline football (25) & 9 & 13 & 3 & \\
volleyball (16) & 9 & 2 & 5 & $21.72^{* *}$ \\
handball (13) & 4 & 3 & 6 & (df=6) \\
bowling (19) & 2 & 4 & 13 & \\
\hline team sports (54 & $\mathbf{2 2}$ & $\mathbf{1 8}$ & 14 & $11.47^{* *}$ \\
individual sports (19) & 2 & 4 & 13 & (df=2) \\
\hline age group 0-19 (24) & 0 & 0 & $\mathbf{2 4}$ & $77.26^{* *}$ \\
age group 20-26(25) & 6 & 16 & 3 & (df $=4)$ \\
age group >26 (24) & 18 & 6 & 0 & \\
\hline
\end{tabular}

In the first cluster, the highest means are found for the items (range of means from 4.04 to 3.42): Your coach seems to have a better relationship with your teammate than with you; A teammate seems to be receiving preferential treatment by the coaching staff; A teammate rarely works hard in practice, however, during competition he/she performs better than you; In practice, your coach encourages another athlete more than you. Overall, the athletes grouped in the first cluster have the highest level of sport jealousy in 7 of possible 11 items (as compared with means for the same items in two other clusters). Therefore, this cluster could be explained as the most jealous. In this cluster are grouped dominantly females, volleyball players (together with a small number of bowling athletes), athletes from team sports and athletes from the oldest age group (Table 1).

Highest means in the second cluster are ranging from 3.23 to 2.77 for following items: You and your teammates have worked hard all season. When the team wins a big competition, you are not recognized for your contribution to the win; Teammates' names are mentioned on the radio from your last contest. Your name is not mentioned; A teammate receives more scholarship money even though you both have equal ability; A teammate is more popular than you are with the other members of the team. Mostly male football players (hence, engaged in team sports) from the middle age group (20-26 years) and team sports are grouped in this cluster. This group of participants is demonstrating a moderate level of sport jealousy, peeking in 4 of possible 11 items (Table 1).

The third cluster is represented by the athletes that can be described as least jealous. This cluster is predominantly contained of females, bowling athletes (with a number of handball players), individual sport participants and those from the youngest age group. Compared to the first two clusters, the third cluster athletes showed low level of overall jealousy (Table 1).

\section{Discussion}

The results confirm that jealousy in sport could be satisfactorily studied even at Croatian sample of athletes. As hypothesized, athletes indicated that they have experienced social comparison jealousy. On average, the athletes were only mildly jealous and only few of them indicated they were extremely jealous.

The participants from this research have been grouped in three clusters, with the most jealous individuals grouped in the first cluster, while the least jealous ones were grouped in the third cluster. More detailed analysis shows that mostly women from the oldest age group who are engaged in team sports indicate the highest scores in level of jealousy. This can be explained in terms of the fact that women in our culture are socially desirable to be more submissive, but relying more on social relationships (Gilligan, 1982) within their group. They probably want to be appreciated when they deserve it, according to their perception. Lower levels of sport jealousy have also been found among females in the youngest age group, practicing mostly bowling and handball. Men from the middle age group practicing team sports (mostly football) show moderate jealousy. Hypothesized submissiveness in women, with simultaneous strong need for social confirmation, could be a reason why women athletes are the most frequently 
grouped in the first (most jealous) cluster, as well as in the least jealous cluster (third). The need for social confirmation could be the main motivation for women athletes grouped in the first (most jealous) cluster, while submissiveness could be leading motive for women athletes grouped in the third cluster.

In the previous research (Kamphoff, Gill, \& Huddleston, 2005), authors suggests that perhaps females experience more jealousy if another athlete has a better relationship with their coach or if another receives more of the coach's attention (especially in an individual sport). On the contrary, in this study female bowling athletes have the lowest jealousy scores, which could be explained by specificity of bowling as a sport. It is coactive team sport, which request desirable (high) team scores, while the individual athletes just want to do their best. The differences in jealousy, found between males and females in football, can be explained with women trend to define themselves in a context of human relationships (Gilligan, 1982). In spite of different types of sports that we have studied, we have found the difference between the athletes engaged in team sports, comparing with individual sport athletes, in the direction of higher scores in jealousy for team sport athletes. On the other hand, all individual athletes and all top athletes, as well as the most of the senior players in our research were from the same sport (bowling), what can have an influence on expected statistically significant trends (in differences) that were found in our research: higher jealousy in juniors (comparing to seniors) and higher jealousy at lower competition ranks. However, differences in jealousy can be explained as a simple reflection of the higher self-confidence at elite athletes, more experienced and older senior athletes.

The limitations of this study and belonging results are few. First, the results obtained from these samples of athletes cannot be generalized to other athletes or other geographic regions. Moreover, the questionnaires were administered either before or after team trainings; hence the athletes could have been in a rush to complete the survey to start practice.

This study could be perceived also as a start point for further research on jealousy in Croatian athletes. It would be important to examine sport jealousy on a larger variety of athletes (differentiated by their sports excellence, age group, sport experience, gender, type of sport, position in team etc.), on a larger sample of participants, such as suggest Kamphoff, Gill \& Huddleston (2005). The specific sample of sports and athletes selected for this research indicate that our results are suggestive but limited, and further research is needed.

Several practical implications arise from this study. The jealousy may have a strong effect on the interpersonal relations within a team. The gender, type of sport (team/ coactive/ individual), athletes' age and level of the sport excellence (top or amateur sport) could be starting points for the coach to understand factors that have an influence on jealousy among athletes. Therefore, the coach and the athletes could be able to cope better with negative consequences of jealousy, improving the performance of the team as a whole, or the performance of individual athletes.

\section{Conclusions}

The participants from this research are grouped in three clusters. The most jealous individuals are grouped in the first cluster, while the least jealous ones were grouped in the third cluster. In the first cluster are grouped dominantly females, volleyball players (together with a small number of bowling athletes), athletes from team sports and athletes from the oldest age group. In second (moderately jealous) cluster are mostly male football players from team sports and in the moderately old age group (20-26 years). Females, bowling athletes and athletes from individual (coactive) sports, as well as participants from the youngest age group, are grouped in third cluster (lowest jealousy). The results provide useful practical implications for coaches' work, as well as for future studies.

\section{REFERENCES}

Bers, S. A., \& Rodin, J. (1984). Social comparison jealousy: A developmental and motivational study. Journal of Personality and Social Psychology, 47, 766-779.

Bringle, R. B., Roach, S., Andler, C., \& Evenbeck, S. (1977). Correlates of jealousy. Presented at The annual meetings of the Midwestern Psychological Association, Chicago, IL. 
Bringle, R. B., Roach, S., Andler, A., \& Evenbeck, S. (1979). Measuring the intensity of jealous reactions. JSAS: Catalog of Selected Documents in Psychology, 9, 23-24.

Gilligan, C. (1982). In a different voice: Psychological theory and women's development. Cambridge, MA: Harvard University Press.

Kamphoff, C.S., Gill, D.L, \& Huddleston, S. (2005). Jealousy in Sport: Exploring Jealousy's Relationship to Cohesion. Journal of Applied Sport Psychology, 17, 290-305.

Mathes, E. W., \& Severa, N. (1981). Jealousy, romantic love, and liking: Theoretical considerations and preliminary scale development. Psychological Reports, 49, 23-31.

Parker, P. (2001). The relationship between jealousy and self-esteem in collegiate athletes. Unpublished masters thesis, Georgia Southern University.

Pease, D. G. (1987). Social comparison jealousy and its relationship to group cohesion [Abstract]. In Psychology of motor behavior and sport (pp. 161). Proceedings of the North American Society for Psychology and Sport and Physical Activity annual convention. Knoxville, TN.

Salovey, P., \& Rodin, J. (1984). Some antecedents and consequences of social comparison jealousy. Journal of Personality and Social Psychology, 47, 780-792.

Schelling-Kamphoff, C., \& Huddleston, S. (1999). Jealousy in collegiate track and field athletes. Proceedings of the Association for the Advancement of Applied Sport Psychology annual convention. Banff, Alberta, Canada.

Silver, M., \& Sabini, J. (1978). The perceptions of envy. Social Psychology, 41, 105-111.

Sindik, J., \& Lorger, M. (2011). The application of the Sport Jealousy Scale (SJS) at Croatian athletes. Sport Science, 4(2), 79-84.

Datum prijave: 17.03.2016.

Datum prihvatanja: 15.06. 2016.

\section{Kontakt}

Joško Sindik, Institute for Anthropological Research,

Zagreb, Ljudevita Gaja 32, Croatia

E-mail: josko.sindik@inantro.hr

Ana-Mary Bauer Čuk, Institute for Anthropological Research, Zagreb, Ljudevita Gaja 32, Croatia

E-mail: ured@inantro.hr 